\title{
The Effect of Diversification of Income towards the Performance of Banks Listed in the Indonesia Stock Exchange
}

\author{
Catur Rahayu Martiningtiyas ${ }^{1}$, Susy Muchtar ${ }^{2}$, Pratiwi Andini Ristiqomah ${ }^{3}$, Mahdaniyyah \\ Rahman $^{4}$ \\ \{catur.rahayu@trisakti.ac.id ${ }^{1}$ \}
}

Management Study Program, Faculty of Economics and Business, Trisakti University

\begin{abstract}
This study aims to analyze the effect of income diversification on bank performance. The independent variable in this study is income diversification, with the control variables are CAR, LDR, NPL and the dependent variable is bank performance (SHROA and SHROE). The sample used in this study is a company engaged in banking companies listed on the Indonesia Stock Exchange (IDX) for the period 2015-2019. The number of samples used in this study amounted to 30 banking companies using purposive sampling. The results of the study show that the income diversification and NPL variables have a significant negative effect on bank performance (SHROA and SHROE). The LDR variable has a significant positive effect on bank performance (SHROA and SHROE). While CAR and Bank Size variables have no significant effect on bank performance. Managerial Implications: Banking companies are expected to minimize the use of income diversification to reduce the level of risk, increase the level of credit distribution and monitor credit disbursement so as not to cause credit failures.
\end{abstract}

Keywords: capital adequacy ratio; income diversification; loan to debt ratio; non-performing loans; SHROA and SHROE

\section{Introduction}

The banking sector is currently experiencing a fairly rapid development. This is marked by an increase in the total assets of the banking industry in February 2018 which grew 9.25 percent annually and the increasing proportion of the Indonesian population who use banking services. Developments in the banking industry were also in line with the 1988 Banking Deregulation Policy Package (Pakto 88) which caused many new banks to appear and banks also expanded their activities to non-interest income activities such as commissions, derivative transactions, investments, fees, and others. This supports the pace of the national economy which always grows above $6.5 \%$. The Financial Services Authority (OJK) noted that at least 80 banks have tried to provide digital banking services for their customers. For example, several banks will launch several digital banking product innovations, namely fingerprints and 
video banking which aim to to complement existing digital banking products such as mobile and internet banking.

The number of innovations in the world of banking has led to more diversification of products offered by banks. The theory of the resource base view and the internal market hypothesis argues that diversification can encourage company operating efficiency, expand debt capacity, and reduce taxes [1]. However, there are also potential expenses of strategy of diversification. Brahmin, Kontesa, \& Gilbert state that general diversification can reduce the risk of loan failure, this strategy leads to greater diversification of income sources, which can help banks reduce risks and stabilize earnings, provided that components of profit are disparate and not perfectly correlated [2]. Uzhegova states that diversification of income leads to increased profitability [3]. Meslier, Tacneng, dan Tarazi tested the hypothesis in the US and Europe and found that shifting banking activities to non-traditional activities (Non Interest Income) would increase bank profitability and risk-adjusted profits [4]. Based on research conducted by Brahmin et al., the measurement of profitability uses two basic risk-adjusted profitability measurements (risk-adjusted profits), namely SHROA and SHROE which can be calculated by dividing Return on Assets and Return on Equity with each -respectively its standard deviation [2]. The problem in this study is whether diversification of income affects the performance of banking companies listed in the Indonesia Stock Exchange.

\section{Literature Review}

\subsection{Bank Performance}

Bank financial performance can be used as a guide to analyze the outcomes of company policies, performance, and efficiency [5]. Therefore it is important to measure bank performance. The performance of adequate financial institutions can be measured using profitability. Profitability is important and crucial not only for customers but also for the sustainable growth and survival of financial institutions [6]. In the economic and financial literature, there are a couple indicators used to measure bank performance. The two key indicators are the profitability of assets (Return on Assets and Return on Equities) and Net Interest Margin [5]. Different banks use different measures to measure their performance. There are two main measurements to measure profitability, namely ROA and ROE. This is in line with research conducted by Ismail, Hanif, Choudhary, dan Nisar which uses Return on Equity (ROE) and Return on Assets (ROA) as a measure of bank performance [7]. Likewise Pennathur, Subrahmanyam, dan Vishwasrao; Karakaya and Er; Turkmen and Yigit in a study that also uses ROE and ROA as performance measurements [8]-[10]. However, in this study, based on previous research conducted by Brahmana et al., the measurement of bank performance uses the standard deviation of ROA (SHROA) and standard deviation of ROE (SHROE) to see bank profitability adjusted for risk level [2]. Delpachitra \& Lester (2013), Amidu \& Wolfe (2013), in their research also use risk-adjusted ROE and ROA as a measure of bank performance [11], [12].

\subsection{Diversification of income}

Zhou argues that the total income of conventional banks consists of 2 parts, namely interest income and non-interest income [13]. The non-interest income itself includes charges, commission income, income from foreign currency trading, investment income, and other 
operating income. Diversification of income is a business strategy that allows an entity to enter new business fields with diversified products and services with the aim of reducing risk and increasing profitability. from the difference in interest, but also non-interest income obtained through various financial services and other banking products [13]. Diversification is usually carried out to reduce the risks faced in lending and overcome intense competition in the credit market [13]. Brahmana et al., stated that there was a significant positive effect between diversification of income on bank performance [2]. The higher a bank diversifies its income, the better the bank's performance is.

\subsection{Capital Adequacy Ratio}

Capital Adequacy Ratio (CAR) is a ratio that shows a bank's capability to handle its assets to grow its company and be able to bear all the burdens of the bank's operating activities [14]. Commercial banks require Adequate capital in order to operate more efficiently due to the protection it provides against failure [15]. Capital is part of the bank's obligations that do not have to be repaid and therefore must be available as a buffer in certain conditions such as declining bank assets [16]. Banks are not always profitable, so capital is needed just in case the bank is affected by large losses [17].

\subsection{Loan to Debt Ratio}

Loan to Debt Ratio (LDR) is a comparison of how much credit the bank provides compared to the total assets owned by the bank. LDR is used to measure the bank's capability to meet credit requests through collateral for a number of assets owned [18]. LDR is a calculation of the percentage of the total loan amount to the total amount of assets [2]. The bank's activity is to collect funds from surplus units and lend them to deficit units. From this activity the bank will benefit. The larger the loan, the higher the level of bank profits and will increase profitability [19].

\subsection{Non-Performing Loans}

Non-Performing Loans (NPL) is a ratio used to measure a bank's capability to bear the risk of default on credit payments by debtors [20]. Non-Performing Loans arise from the extension of credit facilities to customers [21]. Kingu, Macha, dan Gwahula classify non-performing loans to banks as doubtful, substandard, and bad loans [22]. The lower the NPL, the lower the credit risk borne by the bank [20].

\subsection{Bank Size}

Menicucci dan Paolucci say that bank size is the size of the bank [23]. Meanwhile, Petria, Capraru dan Ihnatov suggest that bank size is the large number of asset owned by the bank [24]. Banks can achieve a better capital structure based on its size, this is because bank size has an influence on the profits obtained in a bank, where larger sized banks equals greater profit. The size of a bank will affect its capability to bear risks that may arise due to various situations that will be faced in banking activities [25]. Large banks tend to be able to invest a lot of funds into technology development and are able to expand their business lines so that they are able to get more customers. Flamini, Mcdonald, and Schumacher in their research found that there is a positive influence between bank size and bank performance [26]. This 
shows that large banks take advantage of diversification opportunities and attract investors to invest in assets. In addition, banks with large banks usually face high operational costs due to an increase in asymmetric information, because of the financial crisis, there are imperfections and market uncertainties that result in slower recovery in operating costs and have an impact on the decline in bank income. Shows that there is a negative influence between bank size on bank performance, which means that the larger the size of the bank, the lower the bank performance [27]. In addition, Al-Harbi found that there was no effect between bank size on bank profitability [28].

\subsection{Conceptual Framework}

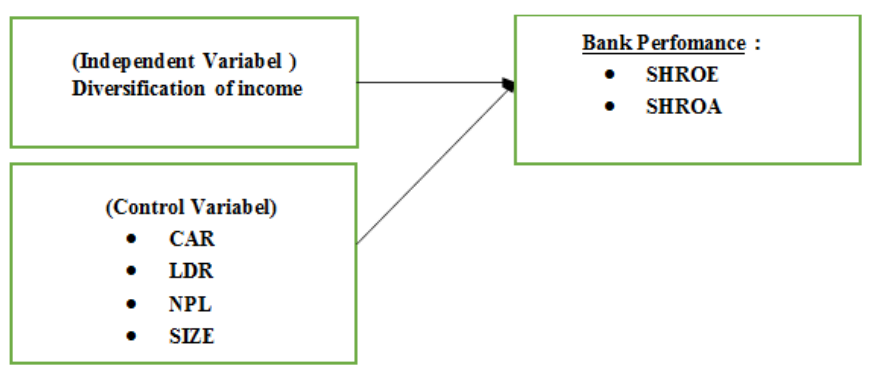

Fig. 1. Conceptual Framework

Hypothesis

$\mathrm{H}_{1}$ : Diversification of income has an effect on Bank Performance

$\mathrm{H}_{2}$ : CAR affect Bank Performance

$\mathrm{H}_{3}$ : LDR affect on Bank Performance

$\mathrm{H}_{4}$ : NPL affect Bank Performance

$\mathrm{H}_{5}$ : Bank Size affect on Bank Performance

\section{Methods of Research}

Table 1. Variables and Measurements

\begin{tabular}{lll}
\hline \multicolumn{1}{c}{ Variables } & \multicolumn{1}{c}{ Measurements } & \multicolumn{1}{c}{ Literature } \\
\hline $\begin{array}{l}\text { Dependent Variable } \\
\text { SHROA }\end{array}$ & ROE / $\sigma$ ROE & Chiorazzo et al.,(2008) \\
SHROE & ROA / $\sigma$ ROA & \\
\hline $\begin{array}{l}\text { Independent Variables } \\
\text { Diversification of income (DIV) }\end{array}$ & $\begin{array}{l}\text { DIV }=1-\left(R N E T^{2}+R N I^{2}\right) \\
\text { Ket }: \text { RNET }=(\text { NET } /(\mathrm{NET}+\mathrm{NII})) \\
\text { RNII }=(\mathrm{NII} /(\mathrm{NET}+\mathrm{NII}))\end{array}$ & \\
& & \\
& & \\
Control Variables & & \\
Capital Adequacy Ratio (CAR) & Modal / Risk Weighted \\
Loan to Debt Ratio (LDR) & Total Kredit / Total Asset \\
Non Performing Loans (NPL) & Kredit Bermasalah / Total Kredit \\
Bank Size (SIZE) & The Natural Logarithm of The & \\
& Total Assets & \\
\hline
\end{tabular}


This study was conducted by means of hypothesis testing which aims to examine the effect of diversification of income, CAR, LDR, NPL and Bank Size on the performance of conventional banks listed in the Indonesia Stock Exchange (IDX) for the period 2015 to 2019 using Multiple Regression Analysis. This study uses secondary data, namely data collected from the company's annual report obtained from the Indonesia Stock Exchange website, namely www.idx.co.id. The regression model of this study can be formulated as follows:

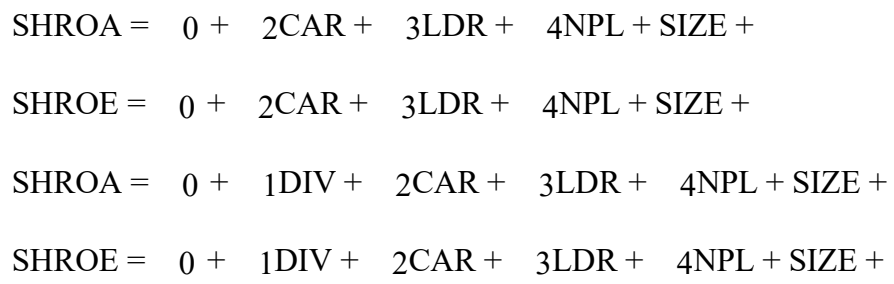

\section{Results and Discussion}

Table 2. Descriptive Statistics

\begin{tabular}{cccccc}
\hline Variabel & Obss. & Mean & Maximum & Minimum & Stand.Dev \\
\hline SHROA & 145 & 7.088622 & 72.91375 & -2.522800 & 13.96002 \\
SHROE & 145 & 4.710184 & 15.93372 & -2.690770 & 4.294315 \\
DIV & 145 & 0.307925 & 0.495110 & 0.018670 & 0.123062 \\
CAR & 145 & 0.204207 & 0.458530 & 0.018670 & 0.059614 \\
LDR & 145 & 0.897391 & 1.463760 & 0.504310 & 0.144575 \\
NPL & 145 & 0.031536 & 0.158210 & $1.00 \mathrm{E}-05$ & 0.020913 \\
SIZE & 145 & 25.10038 & 32.83300 & 22.08341 & 2.116351 \\
\hline
\end{tabular}

Table 3. $\mathrm{T}$ Test Result

\begin{tabular}{|c|c|c|c|c|c|}
\hline Model - 1 & SHROA & & Model - 2 & SHROE & \\
\hline Variable & $\begin{array}{c}\text { Coefficient } \\
\text { (ßeta) }\end{array}$ & $\begin{array}{c}\text { Probcapability } \\
\text { (P-value) }\end{array}$ & Variable & Coefficient (ßeta) & $\begin{array}{c}\text { Probcapability } \\
\text { (P-value })\end{array}$ \\
\hline CAR & 3.051047 & 0.3409 & CAR & -3.068711 & 0.3095 \\
\hline LDR & 3.893490 & $0.0002 *$ & LDR & 3.670246 & $0.0001 *$ \\
\hline NPL & -26.15942 & $0.0000 *$ & NPL & -33.42304 & $0.0000 *$ \\
\hline SIZE & -0.194580 & 0.6489 & SIZE & -0.716057 & $0.0382 *$ \\
\hline
\end{tabular}

Table 4. $\mathrm{T}$ Test Result

\begin{tabular}{cccccc}
\hline Model - 3 & SHROA & & Model - 4 & SHROE & \\
\hline Variable & $\begin{array}{c}\text { Coefficient } \\
(\boldsymbol{\beta e t a})\end{array}$ & $\begin{array}{c}\text { Probcapability } \\
(\boldsymbol{P} \text {-value })\end{array}$ & Variable & Coefficient (ßeta) & $\begin{array}{c}\text { Probcapability } \\
(\boldsymbol{P} \text {-value })\end{array}$ \\
\hline DIV & -3.005206 & $0.0305^{*}$ & DIV & -3.479085 & $0.0084^{*}$ \\
CAR & 3.463476 & 0.2247 & CAR & -2.396382 & 0.4094 \\
LDR & 3.650264 & $0.0000^{*}$ & LDR & 3.646603 & $0.0001^{*}$ \\
NPL & -28.53325 & $0.0000^{*}$ & NPL & -33.31203 & $0.0000^{*}$ \\
SIZE & -0.086945 & 0.8325 & SIZE & -0.880756 & $0.0117^{*}$ \\
\hline
\end{tabular}

*Signifikan pada alpha $0.05(5 \%)$ 


\subsection{Diversification - Bank Performance}

The data analysis came to a conclusion that there is a significant negative effect between diversification of income on bank performance (SHROA \& SHROE). The results of this study are not in line with research conducted by Brahmin et al., which states that there is a positive and significant effect between diversification of income on bank performance (SHROA \& SHROE) [2]. However, these results are in line with the research done by Fiordelisi ,MarquesIbanez, \& Molyneux which states that there is a negative and significant relationship between diversification of income and bank risk [29]. Banks that are profitable and contribute to banking system stcapability are banks that only focus on interest income rather than banks that diversify their income. With the increase in bank risk, it will cause a decrease in profitability and a decrease in the performance of the bank itself.

\subsection{CAR - Bank Performance}

Based on the results of data analysis, it shows that CAR does not affect bank performance (SHROA and SHROE) significantly. The results of this study do not match the research conducted by Brahmin et al. meaning that CAR affects bank performace significantly in a positive way, but the study results match the research conducted by Alper, Wibowo and Mawardi which shows that capital adequacy ratio does not affect bank performace significantly [2], [14], [30]. This shows that high or low CAR does not impact banking performance, both in terms of SHROA and SHROE. Bank Indonesia regulates the banks to maintain a minimum of $8 \%$ capital adequacy ratio, so that bank owners increase bank capital only so that the capital adequacy ratio meets the requirements set by Bank Indonesia and does not try to make the capital able to have a significant influence on bank performance. On the other hand, the banking business is a business that prioritizes trust, so as long as the public believes in the credibility of the bank, the required bank capital of $8 \%$ will not affect the bank's performance.

\subsection{LDR - Bank Performance}

The results of data analysis show that the loan to debt ratio positively affects bank performance (SHROA and SHROE) by a landslide. The results of this study are in the same lane as the research conducted by Brahmin et al., which explains that the loan to debt ratio has a positive and significant effect on bank performance where higher loan to debt ratio indicates higher capabilites of a bank to channel credit through collateral for a number of assets owned by the bank [2]. The higher the loan disbursed, the higher the interest income earned, thereby helping to improve the bank's performance.

The results of this study stay on course with the research conducted by Gul et al., which shows that there is a positively significant effect between loan to debt ratio and bank performance [18]. Sasrosuwito and Suzuki also support the results of this study which explains the positive and significant influence between loan to debt ratio and bank performance [31].

\subsection{NPL - Bank Performance}

Based on the results of data analysis, it shows that non-performing loans (NPL) 
significantly affect bank performance (SHROA and SHROE) in a negative way. The results of this study are not in line with the research of Brahmin et al. which shows that NPL has does not affect bank performance, which defines that the size of a bank's NPL level cannot improve bank performance [2]. However, the results of this study goes well with the research from Roman and Tomuleasa which explains that non-performing loans have a significant negative effect on bank performance [32]. This is because the higher the NPL ratio, the higher the amount of credit that cannot be returned by the debtor so that it can reduce bank profitability and performance. Ally; Hallunovi and Berdo also support this study which shows a negative influence between NPL and bank performance [33], [34].

\subsection{SIZE - Bank Performance}

The results of the study shows that bank size does not influence bank performance (SHROA) but affects bank performance (SHROE) significantly in a negative way. The results of this study are in line with research conducted by Al-Harbi (2019) which found there was no effect between bank size on bank performance.

\section{Conclusion}

This study aims to determine and examine the effect of diversification of income and control variables, namely capital adequacy ratio, loan to debt ratio and non-performing loans on bank performance in conventional banking companies with a sample of 30 banks using financial statement data from the Indonesia Stock Exchange for five years, the last period 2013-2019. The conclusions from the results of the analysis and discussion of the research that have been described are as follows:

1. Diversification of income affects bank performance (SHROA and SHROE) negatively.

2. Capital adequacy does not influence bank performance (SHROA and SHROE)

3. Loan to debt ratio affects bank performance (SHROA and SHROE) positively.

4. Non-performing loans negatively affects bank performance (SHROA and SHROE).

5. Bank Size does not affect bank performance (SHROA) but affects bank performance (SHROE) negatively.

\section{References}

[1] T. Zahavi dan D. Lavie, "Intra-industry diversification and firm performance," Strateg. Manag. J., vol. 34, no. 8, hlm. 978-998, 2013, doi: doi.org/10.1002/smj.2057.

[2] R. Brahmana, M. Kontesa, dan R. E. Gilbert, "Income diversification and bank performance: Evidence from Malaysian banks," Econ. Bull., vol. 38, no. 2, hlm. 799809, 2018, doi: doi.org/10.1007/s10693-008-0029-4.

[3] O. Uzhegova, "The Relative Importance of Internal Factors for Bank Performance in Developed and Emerging Economies," Mediterr. J. Soc. Sci., vol. 6, no. 3, hlm. 277288, 2015, doi: https://doi.org/10.5901/mjss.2015.v6n3p277.

[4] C. Meslier, R. Tacneng, dan A. Tarazi, "Is bank income diversification beneficial? Evidence from an emerging economy," J. Int. Financ. Mark. Institutions Money, vol. 31, no. 1, hlm. 97-126, 2014, doi: doi.org/10.1016/j.intfin.2014.03.007.

[5] M. Nouaili, E. Abaoub, dan A. Ochi, "The Determinants of Banking Performance in 
Front of Financial Changes : Case of Trade Banks in Tunisia," Int. J. Econ. Financ., vol. 5, no. 2, hlm. 410-417, 2015, doi: https://doi.org/21464138.

[6] J. A. Bikker, "Measuring Performance of Banks : An Assessment," J. Appl. Bus. Econ., vol. 11, no. 4, hlm. 141-159, 2010.

[7] A. Ismail, R. Hanif, S. Choudhary, dan A. Nisar, "Income-Diversification In Banking Sector Of Pakistan: A 'blessing' Or 'curse'?,” J. Commer., vol. 7, no. 1, hlm. 11-22, 2015.

[8] A. K. Pennathur, V. Subrahmanyam, dan S. Vishwasrao, "Income diversification and risk: Does ownership matter? An empirical examination of Indian banks," J. Bank. Financ., vol. 36, no. 8, hlm. 2203-2215, 2012, doi: doi.org/10.1016/j.jbankfin.2012.03.021.

[9] A. Karakaya dan B. Er, "Noninterest (Nonprofit) Income and Financial Performance at Turkish Commercial and Participation Banks," Int. Bus. Res., vol. 6, no. 1, hlm. 106117, 2012, doi: doi.org/10.5539/ibr.v6n1p106.

[10] S. Y. Turkmen dan I. Yigit, "Diversification in Banking and its Effect on Banks' Performance : Evidence from Turkey," Am. Int. J. Contemp. Res., vol. 2, no. 12, hlm. 111-119, 2012.

[11] S. Delpachitra dan L. Lester, "Non-Interest Income: Are Australian Banks Moving Away from their Traditional Businesses?," Econ. Pap. A J. Appl. Econ. Policy, vol. 32, no. 2, hlm. 190-199, 2013, doi: doi.org/10.1111/1759-3441.12032.

[12] M. Amidu dan S. Wolfe, "The effect of banking market structure on the lending channel: Evidence from emerging markets," Rev. Financ. Econ., vol. 22, no. 4, hlm. 146-157, 2013, doi: doi.org/10.1016/j.rfe.2013.05.002.

[13] K. Zhou, "The Effect of Income Diversification on Bank Risk: Evidence from China," Emerg. Mark. Financ. Trade, vol. 50, no. sup3, hlm. 201-213, 2014, doi: doi.org/10.2753/REE1540-496X5003S312.

[14] D. Alper dan A. Anbar, "Bank Specific and Macroeconomic Determinants of Commercial Bank Profitability: Empirical Evidence from Nigeria," Int. J. Financ. Bank. Stud., vol. 6, no. 1, hlm. 25, 2011, doi: https://doi.org/10.20525/ijfbs.v6i1.627.

[15] R. Gudmundsson, K. Ngoka-Kisinguh, dan M. Odongo, "The Role of Capital Requirements on Bank Competition and Stability: The Case of the Kenyan Banking Industry," (WPS/02/13), 2013. doi: https://doi.org/10.1080/03079450050045431.

[16] G. Thumbi, "Effects of Credit Risk and Working Capital on Capital Adequacy for Commercial Banks in Kenya," University of Nairobi, 2014.

[17] J. J. Kipruto, J. M. Wepukhulu, dan O. P. Osodo, "The Influence of Capital Adequacy Ratio on the Financial Performance of Second-Tier Commercial Banks in Kenya," Int. J. Bus. Manag. Rev., vol. 5, no. 10, hlm. 13-23, 2017.

[18] S. Gul, F. Irshad, dan K. Zaman, "Factors Affecting Bank Profitability in Pakistan," Rom. Econ. J., vol. 14, no. 39, hlm. 61-87, 2011.

[19] Syafri, "Factors Affecting Bank Profitability in Indonesia," 2012.

[20] D. Kusmayadi, "Analysis of Effect of Capital Adequacy Ratio, Loan to Deposit Ratio, Non Performing Loan, Bopo, and Size on Return on Assets in Rural Banks at Indonesia," Saudi J. Bus. Manag. Stud., hlm. 786-795, 2018, doi: 10.21276/sjbms.2018.3.7.4.

[21] M. Inekwe, "The Relationship between Real GDP and Non-performing Loans: Evidence from Nigeria (1995 - 2009)," Int. J. Capacit. Build. Educ. Manag., vol. 2, no. 1, hlm. 2350-2312, 2013.

[22] P. Stephen Kingu, D. S. Macha, dan D. R. Gwahula, "Impact of Non-Performing Loans 
on Bank’s Profitability: Empirical Evidence from Commercial Banks in Tanzania," Int. J. Sci. Res. Manag., vol. 6, no. 01, 2018, doi: doi.org/10.18535/ijsrm/v6i1.em11.

[23] E. Menicucci dan G. Paolucci, "The Determinants of Bank Profitability: Empirical Evidence from European Banking Sector," J. Financ. Report. Account., vol. 14, no. 1, 2016, doi: https://doi.org/10.1108/jfra-05-2015-0060.

[24] N. Petria, B. Capraru, dan I. Ihnatov, "Determinants of Banks' Profitability: Evidence from EU 27 Banking Systems," Procedia Econ. Financ., vol. 20, no. 15, hlm. 518-524, 2015, doi: https://doi.org/10.1016/s2212-5671(15)00104-5.

[25] A. M. Lipunga, "Determinants of Profitability of Listed Commercial Banks in Developing Countries: Evidence from Malawi," Res. J. Financ. Account., vol. 5, no. 6, hlm. 41-49, 2014.

[26] V. Flamini, C. McDonald, dan L. Schumacher, "The Determinants of Commercial Bank Profitability in Sub-Saharan Africa," 2009.

[27] N. Ammar dan A. Boughrara, "The impact of revenue diversification on bank profitability and risk: evidence from MENA banking industry," Macroecon. Financ. Emerg. Mark. Econ., vol. 12, no. 1, hlm. 36-70, 2019, doi: https://doi.org/10.1080/17520843.2018.1535513.

[28] A. Al-Harbi, "The determinants of conventional banks profitability in developing and underdeveloped OIC countries," J. Econ. Financ. Adm. Sci., vol. 24, no. 47, hlm. 4-28, 2019, doi: https://doi.org/10.1108/JEFAS-05-2018-0043.

[29] F. Fiordelisi, D. Marques-Ibanez, dan P. Molyneux, "Efficiency and risk in European banking," J. Bank. Financ., vol. 35, no. 5, hlm. 1315-1326, 2011, doi: doi.org/10.1016/j.jbankfin.2010.10.005.

[30] A. P. Wibowo dan W. Mawardi, "Pengaruh Non Interest Income, Growth of Asset, Loan To Asset, Car, Dan Loan Loss Provision To Asset Terhadap Risiko Bank," Management, vol. 6, hlm. 1-14, 2017.

[31] S. Sasrosuwito dan Y. Suzuki, "Post Crisis Indonesian Banking System Profitability: Bank-Specific, Industry-Specific, and Macroeconomic Determinants," in The 2 International Research Symposium in Service Management, 2011, hlm. 588-597.

[32] A. Roman dan I.-I. Tomuleasa, "Analysis of profitability determinants : Empirical evidence of commercial banks in the new EU member states," in Proceedings of the 14th International Conference on Finance and Banking, 2014, hlm. 335-346.

[33] Z. Ally, "Determinants of Banks' Profitability in a Developing Economy: Empirical Evidence from Tanzania," Eur. J. Bus. Manag., vol. 6, no. 31, hlm. 2222-2839, 2014.

[34] A. Hallunovi dan M. Berdo, "The Relationship between Risk Management and Profitability of Commercial Banks in Albania," Asian Themes Soc. Sci. Res., vol. 1, no. 2, hlm. 44-49, 2018, doi: doi.org/10.33094/journal.139.2018.12.44.49. 